\title{
NGR Tumor-Homing Peptides: Structural Requirements for Effective APN (CD13) Targeting
}

\author{
Alessandra Graziadio, ${ }^{\dagger}$ Matteo Zanda, ${ }^{\dagger}{ }^{\dagger}$ Simona Frau, ${ }^{\dagger}$ Ian N. Fleming, ${ }^{\dagger}$ Manuele Musolino, $^{\dagger}$ \\ Sergio Dall'Angelo, ${ }^{\dagger}$ Massimiliano Baldassarre, ${ }^{*}{ }^{\dagger}$ and Monica Piras ${ }^{*},^{\dagger}$ \\ ${ }^{\dagger}$ Kosterlitz Centre for Therapeutics and Aberdeen Biomedical Imaging Centre, University of Aberdeen, Aberdeen, AB25 2ZD, \\ Scotland, United Kingdom \\ ${ }^{\ddagger}$ C.N.R. - I.C.R.M., via Mancinelli 7, 20131 Milan, Italy
}

Supporting Information

\begin{abstract}
Cyclic CNGRC ( $c$ CNGRC) peptides are very important targeting ligands for Aminopeptidase N (APN or CD13), which is overexpressed on the surface of many cancer cells. In this work we have (1) developed an efficient solidphase synthesis and (2) tested on purified porcine APN and APN-expressing human cells two different classes of $c$ CNGRC peptides: the first carrying a biotin affinity tag or a fluorescent tag attached to the carboxyl Arg-Cys- $\mathrm{COOH}$ terminus and the second with the tags attached to the amino $\mathrm{H}_{2} \mathrm{~N}$-Cys-Asn terminus. Carboxyl-terminus functionalized $c$ CNGRC peptides

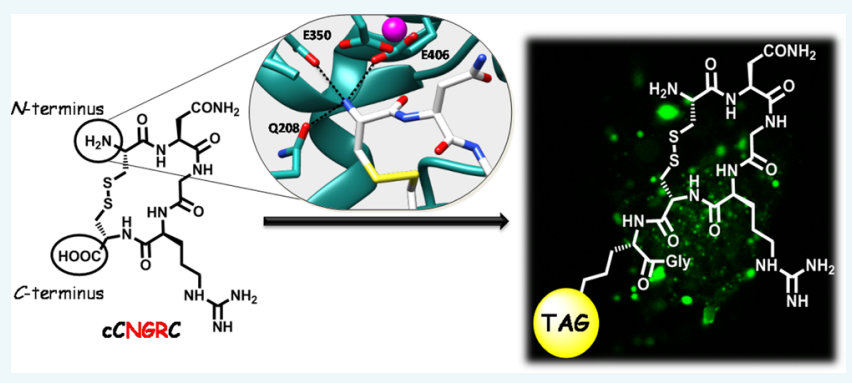
3,6 , and 8 showed good affinity for porcine APN and very good capacity to target and be internalized into APN-expressing cells. In contrast, amino-terminus functionalized $c$ CNGRC peptides 4, 5, and 7 displayed significantly decreased affinity and targeting capacity. These results, which are in agreement with the recently reported X-ray structure of a $c$ CNGRC peptide bound to APN showing important stabilizing interactions between the unprotected $c$ CNGRC amino terminus and the APN active site, indicate that the carboxyl and not the amino-terminus of cCNGRC peptides should be used as a "handle" for the attachment of toxic payloads for therapy or isotopically labeled functions for imaging and nuclear medicine.
\end{abstract}

\section{INTRODUCTION}

Mammalian aminopeptidase $\mathrm{N}(\mathrm{APN}$ or $\mathrm{CD} 13)$ is a transmembrane zinc-dependent metalloprotease involved in a variety of processes, including blood pressure regulation, cell migration, viral uptake, cell survival, and angiogenesis. ${ }^{1}$ As an exopeptidase, APN cleaves amino acids from the $N$-terminal portion of peptides, preferentially recognizing neutral residues such as alanine, leucine, and phenylalanine. APN was shown to be overexpressed in many cancer cells and implicated in tumor progression and invasion. ${ }^{2}$ Accordingly, APN knockdown or inhibition with bestatin 1, a natural substrate analogue, has been shown to significantly impair tumor growth in animal models. ${ }^{2,3}$ APN is selectively recognized by peptides containing the Asn-Gly-Arg (NGR) sequence, a tumor-homing motif discovered by phage display technologies. ${ }^{4,5}$ Owing to their tumor-homing properties, NGR-containing peptides, such as the $c$ CNGRC 2 (Figure 1), have been conjugated to anticancer drugs to generate tumor-targeted therapeutics with enhanced efficacy and reduced off-target toxicity. ${ }^{5,6}$ A noteworthy example is the NGR-TNF- $\alpha$ construct, a tumor-targeted bioconjugate consisting of human tumor necrosis factor $\alpha$ fused to the C-terminus of $c$ CNGRC, which is currently undergoing clinical trials for the treatment of advanced solid tumors either as a single agent or in combination with standard chemotherapy (www.clinicaltrials.gov). ${ }^{6,7}$ The tumor-homing peptide $c$ CNGRC has also been used in molecular imaging probes for in vivo detection of APN expression in solid tumors. Various NGR peptides have been conjugated with signaling molecules for optical imaging, ${ }^{8}$ MRI, ${ }^{9}$ and nuclear imaging techniques, ${ }^{10}$ and the final constructs tested in tumor xenograft models.

Despite the potential of APN-directed tumor-homing strategies, the exact structural requirements necessary for APN-NGR recognition and tumor targeting with NGR peptides are still not completely clear. The crystal structure of porcine APN (which shares a high grade of homology with human APN) complexed with the $c$ (CNGRC)G peptide has recently been reported, revealing important structural information for the development of high-affinity NGR analogues, as well as for the rational design of NGR-based bioconjugates used for site-directed delivery of anticancer drugs and cancer imaging agents. ${ }^{11}$ X-ray crystallographic data showed that the NGR motif binds to the zinc-aminopeptidase active site forming specific interactions through the side chains of asparagine and arginine. The binding mode of the cyclic $c$ CNGRC resembles that of APN natural substrates, ${ }^{12}$ although not surprisingly the

Received: March 10, 2016

Revised: April 12, 2016

Published: April 14, 2016 


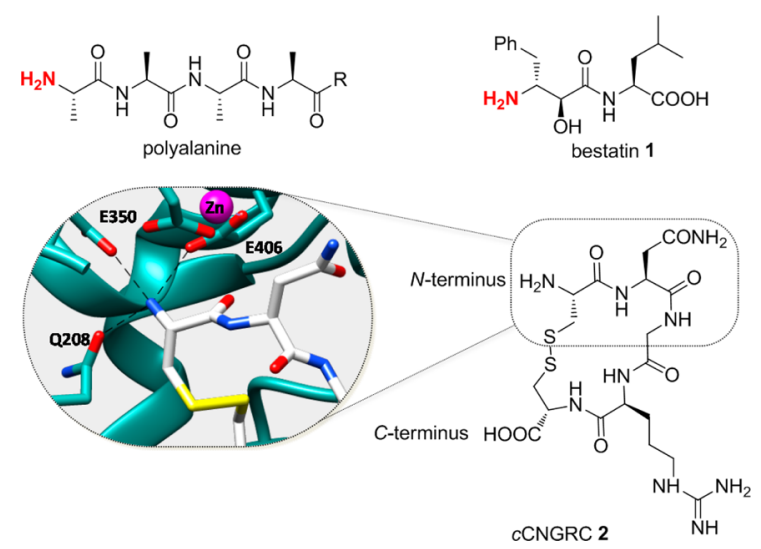

Figure 1. Structures of the APN natural substrate polyalanine, APN inhibitor bestatin $\mathbf{1}$, and $c$ CNGRC tumor-homing peptide $\mathbf{2}$ (crystal structure of the APN catalytic site in complex with $c$ CNGRCG, PDB code 4OU3). The $\mathrm{NH}_{2}$ functions of polyalanine and bestatin recognized by APN as the $\mathrm{N}$-terminal portion of peptides are colored in red.

presumed scissile peptide bond within the cCNGRC backbone was found to be stable against enzymatic hydrolysis (Figure 1). Importantly, the $N$-terminal amino group of APN natural substrates and inhibitors, such as polyalanine and bestatin $\mathbf{1}$ (Figure 1), was shown to play a crucial role in the binding process, forming strong interactions with a negatively charged region of the APN catalytic site. X-ray data showed that the $\mathrm{H}_{2} \mathrm{~N}$-Cys-Asn fragment of the cCNGRC peptide strongly overlaps with the $\mathrm{N}$-terminal $\mathrm{H}_{2} \mathrm{~N}$-Ala-Ala in APN-bound polyalanine, ${ }^{11,12}$ whereas the carboxyl terminus on the second cysteine appears to play a less important role in the binding to APN.

Based on the structural data above, we hypothesized that the carboxyl and not the amino-terminus should be used as a functional "handle" for the synthesis of cCNGRC-bioconjugates, and that the $\mathrm{N}$-terminus should remain in unprotected $\mathrm{NH}_{2}$-form. Surprisingly, this key aspect has never been-to the best of our knowledge-discussed in the literature, where a wide structural range of linear or cyclic NGR peptides has been reported with variable degree of success. In particular, both the $N$-terminus ${ }^{10,13-17}$ and $C$-terminus ${ }^{4,6}$ of $c$ CNGRC have been used as "handles" for bioconjugation, with or without protection of the unused "handle", ${ }^{13}$ apparently without a rational structural design. ${ }^{4,10}$ The aim of this study was to shed light on the role of carboxyl and amino "handles" of $c$ CNGRC constructs in the APN targeting process and also to provide a structural rationale for the design of APN-targeted $c$ CNGRC bioconjugates. To this end, we synthesized a series of $c$ CNGRC derivatives $(3-7$, Table 1$)$ where either the $C$-terminus or the $\mathrm{N}$-terminus were modified by amidation, acetylation, or conjugation with a biotinylated molecular fragment. The effect of these modifications on the capacity of derivatives 3-7 to inhibit the enzymatic activity of APN was investigated, clearly showing that the $\mathrm{N}$-terminus is unsuitable as a handle for bioconjugation and should be present in unprotected $\mathrm{NH}_{2}$ form. Conversely, the $\mathrm{C}$-terminus was identified as the optimal attachment site for the development of $c$ CNGRC-based derivatives targeting APN. Finally, a fluorescent $c$ CNGRCbased probe (8), consisting of Oregon green 488 (OG) fused through a lysine linker with the $C$-terminus of $c$ CNGRC, was synthesized and successfully used for imaging of APN expression on human HT1080 cells.
Table 1. Structures and ESI-MS of Peptides 2-8

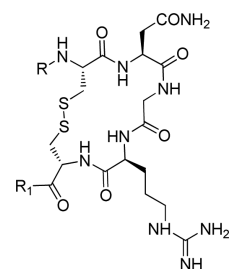

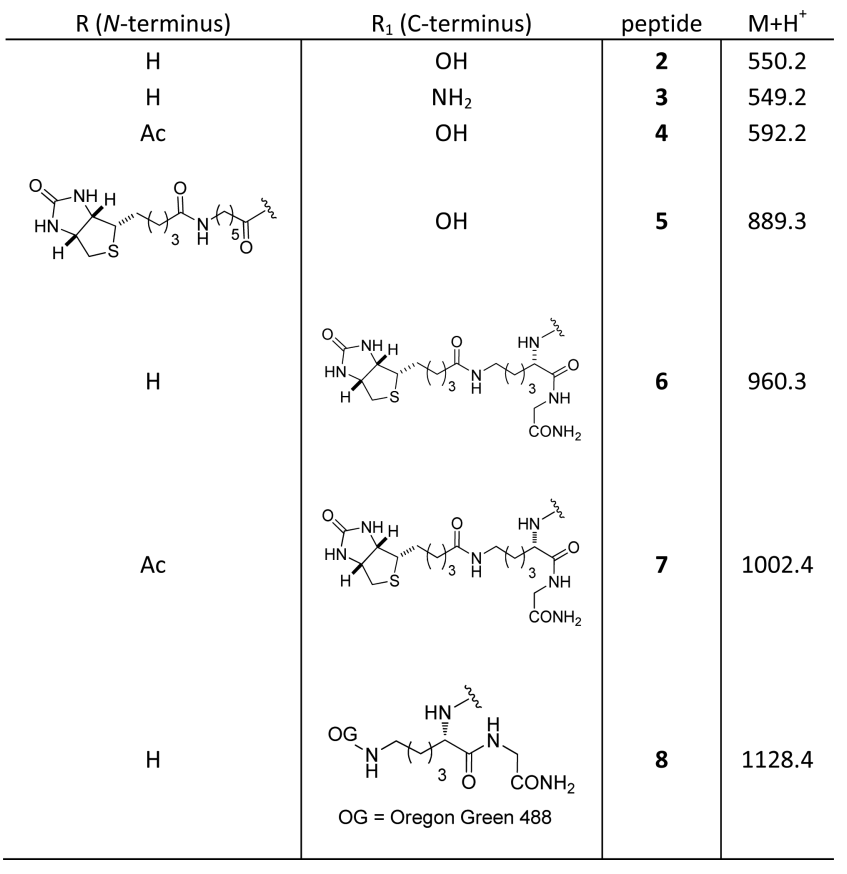

\section{RESULTS AND DISCUSSION}

Synthesis. The following structural modifications were introduced on the $c$ CNGRC peptide 2: (i) the terminal $\mathrm{COOH}$ group was substituted by a $\mathrm{CONH}_{2}(3)$; (ii) the $\mathrm{N}$-terminus was masked by acetylation (4); (iii) the $\mathrm{N}$ - or $\mathrm{C}$-terminus were conjugated to a biotinylated function to give derivatives $\mathbf{5}$ and 6, respectively; (iv) compound $\mathbf{6}$ was further modified by $\mathrm{N}$ terminus acetylation (to give derivative 7 ). Finally, compound 8 was designed like 6 but with a fluorescent tag (Oregon Green 488) replacing the biotinylated function on the $C$-terminus. Molecules 2-8 were prepared via solid-phase peptide synthesis (SPPS) using the Fmoc strategy. Peptides functionalized on the $\mathrm{N}$-terminus and displaying a free $\mathrm{C}$-terminus $(\mathbf{2}, \mathbf{4}$, and $\mathbf{5})$ were assembled on a Fmoc-Cys acetamidomethyl (Acm) preloaded Wang resin. The Fmoc-protected amino acids were coupled in sequence using HATU as a coupling agent (Scheme 1). Biotinylated conjugate $\mathbf{5}$ was obtained by linking the biotin moiety to the CNGRC peptide through 6-aminohexanoic acid $(\varepsilon$-Ahx $)$ as a spacer arm. Cyclization of the linear $\varepsilon$-AhxCNGRC precursor on-resin by forming a disulfide bridge via iodine-mediated oxidation of the thiol groups followed by biotinylation afforded peptide $\mathbf{5}$, albeit in low yields. Cleavage and subsequent cyclization of the precursor 9 and its acetylated derivative in solution phase gave the desired products $\mathbf{2}$ and $\mathbf{4}$, respectively, in slightly better yields. In order to optimize the cyclization step, compound 3 (Scheme 2) was prepared following a different synthetic approach. The acid-labile trityl (Trt) group, which can be removed simultaneously with the cleavage of the linear precursors from the resin, was used as cysteine $S$-protecting group. 
Scheme 1. Synthesis of Derivatives 2,4 , and $5^{a}$

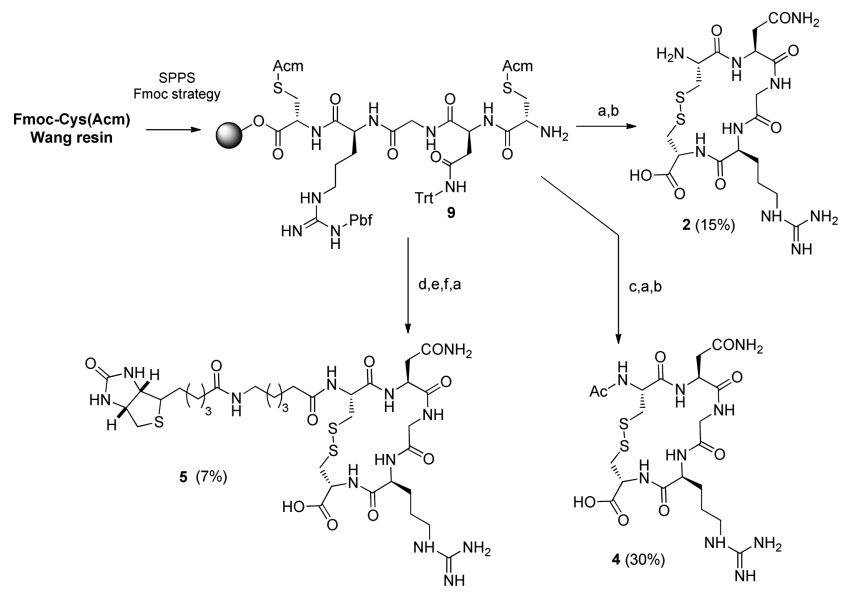

${ }^{a}$ Reagents and conditions: SPPS Fmoc strategy: (Fmoc cleavage) 20\% piperidine in DMF, rt, $10 \mathrm{~min}$; (coupling) Fmoc-amino acid, HATU, DIPEA, DMF, rt, 2 h. Sequence of addition: Fmoc-Arg(Pbf)-OH, Fmoc-Gly-OH, Fmoc-Asn(Trt)-OH, Fmoc-Cys(Acm)-OH. (a) TFA/ TIPS $/ \mathrm{H}_{2} \mathrm{O}$ 95:2.5:2.5, rt, 2 h; (b) $\mathrm{I}_{2}, \mathrm{AcOH}, \mathrm{HCl}, \mathrm{rt}, 2 \mathrm{~h}$; (c) DCM/ Acetic Anhydride/DIPEA 20:4:1, rt, 1 h; (d) (i) Fmoc- $\varepsilon$-Ahx-OH, DIC, Oxyma Pure, DMF, rt, 2 h; (ii) $20 \%$ piperidine in DMF, rt, 10 min; (e) $\mathrm{I}_{2}, \mathrm{DMF} / \mathrm{H}_{2} \mathrm{O}$ 4:1, rt, 4 h; (f) biotin, DIC, Oxyma Pure, DMF, rt, $24 \mathrm{~h}$.

Scheme 2. Synthesis of $3^{a}$

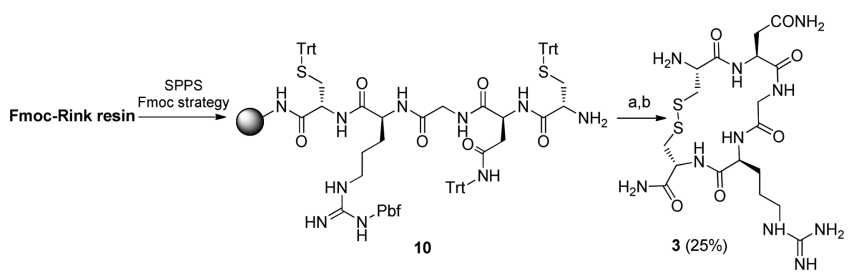

${ }^{a}$ Reagents and conditions: SPPS Fmoc strategy: (Fmoc cleavage) 20\% piperidine in DMF, rt, $10 \mathrm{~min}$; (coupling) Fmoc-amino acid, HATU, DIPEA, DMF, rt, 2 h. Sequence of addition: Fmoc-Cys(Trt)-OH, Fmoc-Arg(Pbf)-OH, Fmoc-Gly-OH, Fmoc-Asn(Trt)-OH, Fmoc-Cys(Trt)-OH; (a) TFA/TIPS $/ \mathrm{H}_{2} \mathrm{O}$ 95:2.5:2.5, rt, 2 h; (b) NCS, $\mathrm{H}_{2} \mathrm{O}$, rt, $15 \mathrm{~min}$.

Peptide 3 was assembled on a Rink resin and the Fmocprotected amino acids were coupled in sequence using HATU as a coupling agent (Scheme 2). After cleavage of the linear precursor $\mathbf{1 0}$ from the resin, the cyclization step was accomplished in solution phase in less than $15 \mathrm{~min}$ by adding $\mathrm{N}$-chlorosuccinimide (NCS) as an oxidizing agent, according to a procedure reported in the literature. ${ }^{18} \mathrm{~A}$ similar strategybased on the use of the acid-labile $p$-methoxytrityl (Mmt) as cysteine $S$-protecting group-was then exploited for conjugates 6-8 which were synthesized on a Rink solid support (Scheme 3). Assembly of the CNGRC sequence was performed after loading the resin with Fmoc-Gly-OH and coupling with FmocLys(Dde)-OH. Once the last amino acid of the heptapeptide sequence (11) was added, the orthogonal protecting group of lysine (Dde) was removed with hydrazine and conjugation with biotin or 5(6)-carboxy-2', $7^{\prime}$-difluorofluorescein (Oregon green 488) - which was freshly synthesized ${ }^{19}$ and used as a mixture of 5- and 6-regioisomers-was accomplished on-resin through the amino function of the lysine side-chain to give intermediates 12 and 13, respectively. For achieving an orthogonal protection between the lysine side chain and the $\mathrm{N}$-terminal group of
Scheme 3. Synthesis of Conjugates $6-8^{a}$

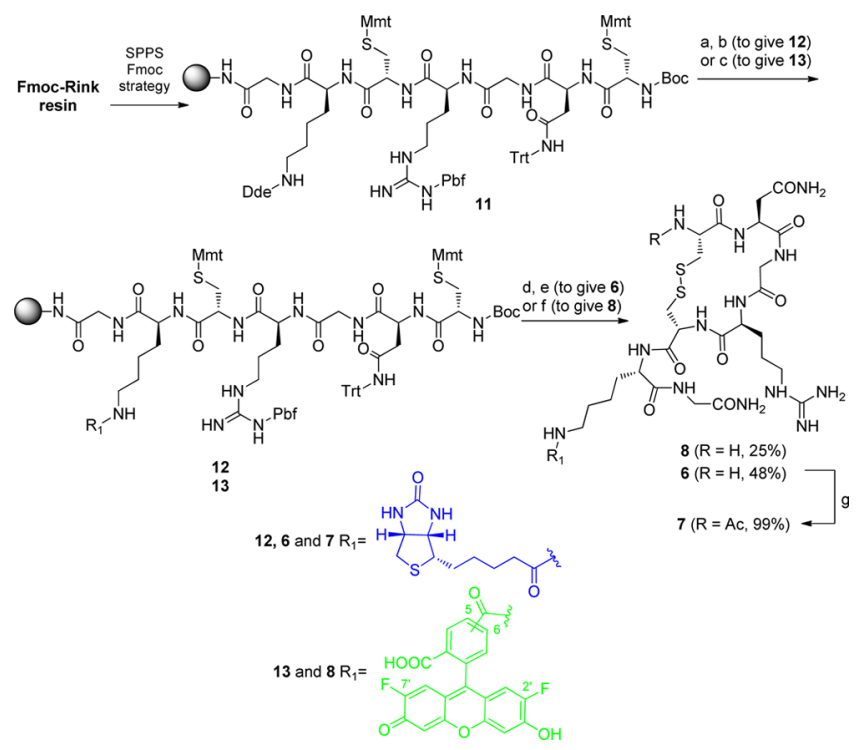

${ }^{a}$ Reagents and conditions: SPPS Fmoc strategy: (Fmoc cleavage) $20 \%$ piperidine in DMF, rt, $10 \mathrm{~min}$; (coupling) Fmoc-amino acid, HATU, DIPEA, DMF, rt, 2 h. Sequence of addition: Fmoc-Gly-OH, FmocLys(Dde)-OH, Fmoc-Cys(Mmt)-OH, Fmoc-Arg(Pbf)-OH, FmocGly-OH, Fmoc-Asn(Trt)-OH, Boc-Cys(Mmt)-OH; (a) $2 \%$ $\mathrm{NH}_{2} \mathrm{NH}_{2}$ in DMF, rt, 3 min; (b) biotin, HATU, DIPEA, DMF, rt, 2 h; (c) Oregon green 488, HATU, DIPEA, DMF, rt, 2 h; (d) TFA/ TIPS $/ \mathrm{H}_{2} \mathrm{O}$ 95:2.5:2.5, rt, $2 \mathrm{~h}$; (e) atmospheric $\mathrm{O}_{2}, 50 \mathrm{mM} \mathrm{PB}, \mathrm{pH}$ 7.4, rt, $72 \mathrm{~h}$; (f) NCS, $\mathrm{H}_{2} \mathrm{O} / \mathrm{CH}_{3} \mathrm{CN}$ 9:1, rt, $15 \mathrm{~min}$; (g) acetic anhydride, $\mathrm{H}_{2} \mathrm{O}, \mathrm{rt}, 10 \mathrm{~min}$.

peptide 11, the last amino acid added to the sequence was protected as $\mathrm{N}$-Boc derivative (Boc-Cys $(\mathrm{Mmt})-\mathrm{OH}$ ). The Fmoc protecting group is, in fact, cleaved simultaneously with Dde upon treatment with hydrazine. Precursor 13 was cleaved from the solid support and the desired conjugate $\mathbf{8}$ was obtained performing the cyclization step in solution phase using NCS. On the other hand, after cleavage of the biotinylated precursor 12 from the resin, conjugates 6 and 7 were prepared forming the disulfide bond by air oxidation. (Note: Treatment of biotinylated linear peptides with NCS resulted in a mixture of undesired byproducts, probably because the biotin moiety does not tolerate strong oxidation conditions.)

APN Inhibition Assay. Peptide 2 and its derivatives 3-7 were examined for their inhibitory activity toward porcine APN using a spectrophotometric assay commonly employed for screening APN inhibitors. ${ }^{12,20,21}$ Briefly, APN and the substrate L-leucine- $p$-nitroanilide were incubated for $1 \mathrm{~h}$ in the presence of gradient concentrations of peptides 2-7 and formation of the product $p$-nitroaniline was measured reading absorbance at $405 \mathrm{~nm}$. Bestatin 1, a potent APN inhibitor, was included in the assay as a positive control, while biotin was used as a negative one. The results of the assay are summarized in Table 2 and in Figure 2, which show the effects of $C$ - or $N$-terminus functionalization on the activity of $c$ CNGRC 2 . In accordance with data previously reported, ${ }^{20}$ the inhibitory potency of cCNGRC 2 was considerably lower than that of 1 (about 120fold, Table 2). Replacement of the $C$-terminus $\mathrm{COOH}$ of 2 with a $\mathrm{CONH}_{2}$ function (derivative 3 ) had negligible effect on the inhibitory potency of the parent peptide (Table 2 and Figure 2a,b). Conversely, the activity was markedly impaired upon $\mathrm{N}$-terminus acetylation (compound 4 ) or by conjugation 
Table 2. $\mathrm{IC}_{50}$ Values of Bestatin 1 and NGR Peptides $2-7^{a}$

$\begin{array}{lc}\text { compound } & \mathrm{IC}_{50}(\mu \mathrm{M}) \\ \text { Bestatin 1 } & 5.1 \\ 2 & 636 \\ 3 & 620 \\ 4 & >1000 \\ 5 & >1000 \\ 6 & 43.3 \\ 7 & >1000\end{array}$

${ }^{a} \mathrm{IC}_{50}$ values were calculated from concentration-response curves by a nonlinear regression analysis using GraphPad Prism Software.

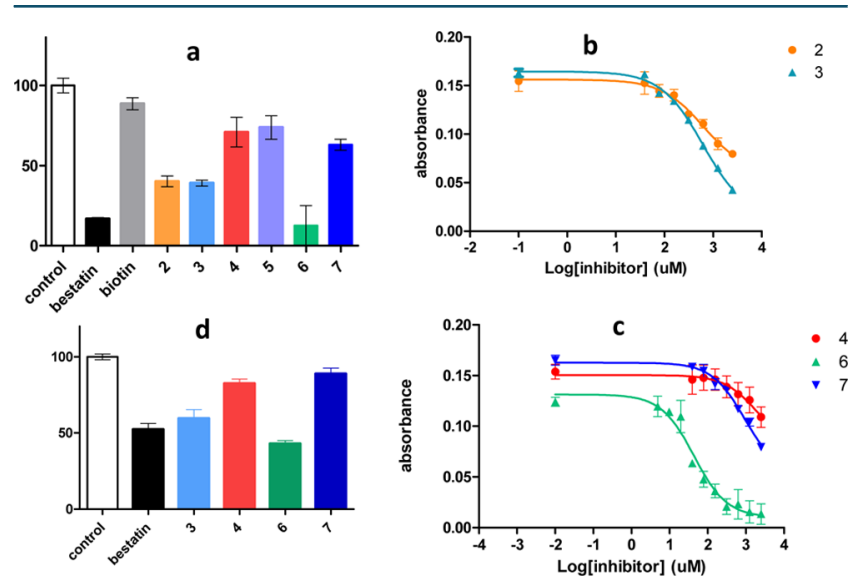

Figure 2. (a) Effect of bestatin $1(25 \mu \mathrm{M})$, biotin $(1.25 \mathrm{mM})$, and peptides 2-7 $(1.25 \mathrm{mM})$ on the enzymatic activity of APN. The results are expressed as percentage of APN residual activity relative to the catalytic activity of APN in the absence of any inhibitor taken as 100\%; (b) inhibition of APN by peptides 2 and 3; (c) inhibition of APN by peptides 4,6 , and $7 ;(a-c)$ data are the average of two independent experiments performed in duplicate, with error bars displaying standard deviations; (d) inhibition of APN expressed on HT1080 cells by bestatin $1(25 \mu \mathrm{M})$ and NGR inhibitors $(1.25 \mathrm{mM})$. The results are expressed as percentage of APN residual activity relative to the untreated control $(100 \%)$. The data are the average of three replicates with error bars displaying standard deviations.

of this function to a biotinylated linker (compound 5). As shown in Figure 2a, at a concentration of $1.25 \mathrm{mM}$ of peptides 4 and 5 the inhibition of APN activity was less than $30 \%$. Interestingly, bioconjugate $\mathbf{6}$ (consisting of biotin fused through a lysine linker to the $C$-terminus of $c$ CNGRC 2) showed an increased inhibitory potency relative to the parent peptide 2 (almost 15-fold, Table 2). The latter result is in accordance with the $\mathrm{IC}_{50}$ value of $38.7 \mu \mathrm{M}$ reported in the literature ${ }^{11}$ for the $c$ (CNGRC)G peptide, suggesting that an additional amino acid directly linked to the $C$-terminus of $c$ CNGRC peptides can lead to an increase of APN inhibitory potency. Similarly to what was previously observed with the $N$-acetylated derivative 4, acetylation of the free $\mathrm{N}$-terminus significantly impaired the activity of the resulting $C$-biotinylated compound 7 (Figure $2 \mathrm{a}, \mathrm{c})$. Overall, these results show that the $C$-terminus is the optimal "handle" for cCNGRC peptides derivatization, whereas the $\mathrm{N}$-terminus must remain in free $\mathrm{NH}_{2}$ form for achieving higher APN inhibitory activity.

APN Inhibition Assay on HT1080 Cells. To further confirm these results in a more physiological system, we measured the inhibitory activities of $C$-derivatives 3 and $\mathbf{6}$ and the corresponding $\mathrm{N}$-acetylated derivatives 4 and 7 toward human APN expressed on the surface of living cells. We selected the human fibrosarcoma cell line (HT1080) which is known to express high levels of APN and has been extensively used to measure human APN activity. Adherent HT1080 cells and the substrate L-leucine-p-nitroanilide were incubated for $1 \mathrm{~h}$ in the presence of gradient concentrations of inhibitors and formation of the product $p$-nitroaniline was measured on a plate reader at $405 \mathrm{~nm}$. Bestatin 1 was included in the test as a positive control. As shown in Figure 2d, the inhibitory activities of the tested compounds exactly replicated the results obtained with the purified enzyme. The $N$-acetylated derivative 4 showed reduced activity compared to 3 , while the $C$-biotinylated 6 displayed the highest inhibitory potency of the series. The activity of the $N$-acetylated derivative 7 was significantly reduced, in complete agreement with the results previously obtained with the purified enzyme.

Imaging of APN in HT1080 Cells with cCNGRCKG-OG Bioconjugate 8. A cCNGRC peptide carrying a fluorescent moiety at the $C$-terminus $c$ CNGRCKG-OG 8 was then used to image APN in living cells. Oregon green was selected as fluorescent probe because its high quantum efficiency and resistance to photobleaching make it a good and flexible tool for both wide-field and confocal imaging. ${ }^{19}$ To decide the best concentration for APN detection on HT1080, cells were incubated at $0{ }^{\circ} \mathrm{C}$ for $1 \mathrm{~h}$, then fixed and imaged under a fluorescent microscope at $20 \times$ magnification. We found that the fluorescent signal was saturable and approached the maximum with a cCNGRCKG-OG 8 concentration of 100 $\mu \mathrm{M}$ (Figure 3a,b). More importantly the binding of the fluorescent probe was greatly reduced in the presence of bestatin $1(100 \mu \mathrm{M})$ or cCNGRCKG-biotin $6(1 \mathrm{mM})$, confirming that the binding is indeed through APN (Figure 3c). It has been shown that APN is rapidly internalized after binding on the cell surface. ${ }^{22}$ The internalization is fundamental for some of the APN functions and is exploited by some coronavirus to enter and infect epithelial cells. ${ }^{23}$ In addition, APN internalization has been used to specifically target cancer cells with NGR conjugated to cytotoxic agents. We therefore analyzed the ability of the fluorescent probe 8 to undergo APNmediated endocytosis. As shown in Figure $3 \mathrm{~d}$ the fluorescent conjugate $\mathbf{8}$ is fully internalized and present in intracellular vesicles after $1 \mathrm{~h}$ at $37^{\circ} \mathrm{C}$.

\section{CONCLUSIONS}

This study paves the way for a more rational use of $c$ CNGRC peptides as targeting vectors in therapy and imaging. First of all, we have developed an efficient solid-phase synthesis of cCNGRC peptides and conjugates carrying different functional tags on either the amino- or the carboxyl-terminus, which could be prepared on a scale of hundreds of milligrams. In agreement with the recently reported X-ray structure of a cCNGRC peptide bound to porcine $\mathrm{APN},{ }^{11}$ we have shown that the optimal conjugation site-or "handle"-for linkers carrying a biotin affinity tag or a fluorescent moiety is the Arg-Cys-COOH $C$-terminus, which preserves the capacity of CNGRC peptides to bind and inhibit APN. Conversely, the $\mathrm{H}_{2} \mathrm{~N}$-Cys-Asn $\mathrm{N}$ terminus must be present in free form as it appears to be involved in key interactions with the APN active site. Since (1) the porcine APN residues involved in the binding to $c$ CNGRC peptides are completely conserved between human and porcine APNs, and (2) APN inhibitory activity of peptides 3-7 and cell internalization capacity of $\mathbf{8}$ were also confirmed on human cells, these results should be translatable to the development of more efficient $c \mathrm{CNGRC}$ constructs, conjugates, and theranos- 


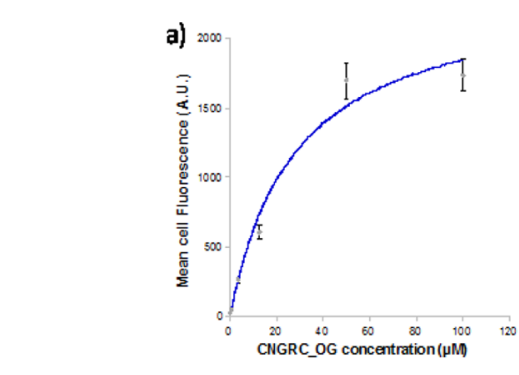

b) $C$ CNGRCKG-OG
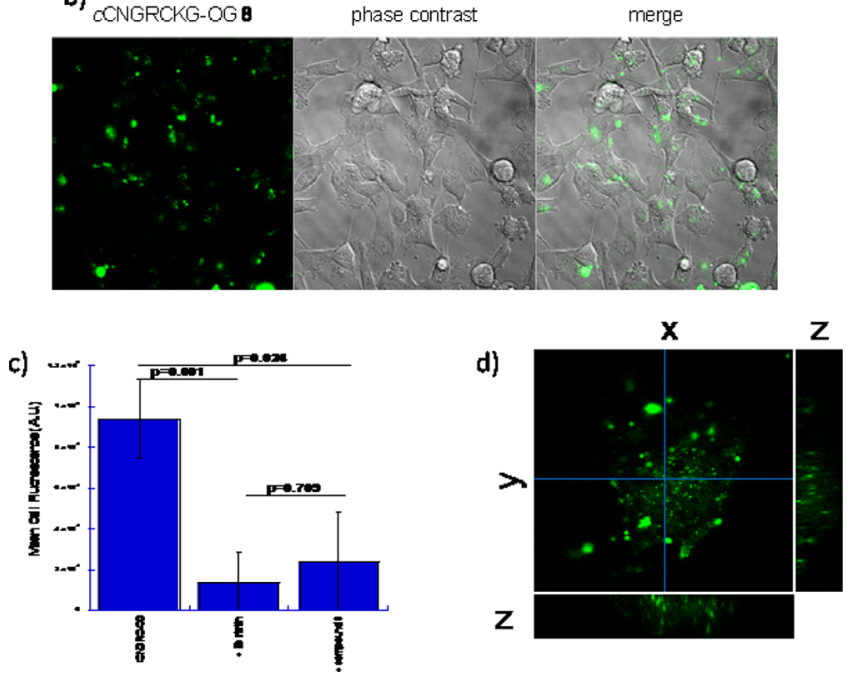

Figure 3. Tracer binding studies of $c$ CNGRCKG-OG 8 on HT1080 cells. (a) Binding curve of cCNGRCKG-OG 8 on HT1080 human fibrosarcoma cells. (b) Incubation with tracer 8 shows binding to HT1080 cells. (c) Quantification of the fluorescent signal present in the cells showing that the binding of fluorescent probe 8 to HT1080 cells is effectively inhibited by coincubation with bestatin $(100 \mu \mathrm{M})$ and $c$ CNGRCKG-biotin $6(1 \mathrm{mM})$. (d) Internalization of the probe 8 via $\mathrm{APN}$-mediated endocytosis.

tics carrying toxic payloads or radioisotopes for preclinical and clinical use.

\section{EXPERIMENTAL PROCEDURES}

${ }^{1} \mathrm{H}$ NMR, ${ }^{13} \mathrm{C} \mathrm{NMR}$, and ${ }^{19} \mathrm{~F}$ NMR spectra were recorded on a Bruker AVANCE III 400 NMR spectrometer. Chemical shifts $(\delta)$ are reported in parts per million (ppm) and coupling constants $(J)$ are given in Hertz $(\mathrm{Hz})$. The abbreviations $\mathrm{s}, \mathrm{d}$, $\mathrm{dd}, \mathrm{t}, \mathrm{m}$, and brs stand for singlet, doublet, doublet of doublets, triplet, multiplet, and broad singlet, in that order. All ${ }^{13} \mathrm{C}$ NMR spectra were proton decoupled. Mass analyses were performed using Agilent 1200 HPLC system coupled to Agilent G6120 single quadrupole detector equipped with an electrospray ionization (ESI) source in direct infusion modality. ESI-MS spectra were recorded in positive mode. RP (reverse phase) HPLC-MS analyses were performed with an Agilent 1200 HPLC system equipped with a DAD and an ESI-MS detector. HPLC conditions for analytical analyses: Phenomenex Luna C18 column, $5 \mu \mathrm{m}, 100 \AA ̊, 250 \times 4.6 \mathrm{~mm}(\mathrm{~L} \times \mathrm{ID})$, inj. volume $20 \mu \mathrm{L}$, flow rate $1 \mathrm{~mL} / \mathrm{min}$. HPLC conditions for semipreparative purification: Phenomenex Luna C18 column, $5 \mu \mathrm{m}$, $100 \AA$, $250 \times 10.0 \mathrm{~mm}(\mathrm{~L} \times \mathrm{ID})$, flow rate $5 \mathrm{~mL} / \mathrm{min}$. The amount of TFA in the purified peptides was quantified by ${ }^{19} \mathrm{~F}$ NMR using 2,4-dinitro-fluorobenzene as an internal standard.

Synthesis of cCNGRC 2. Fmoc-Cys(Acm) Wang resin (500 mg, $0.30 \mathrm{mmol}$, loading: $0.60 \mathrm{mmol} / \mathrm{g}$ ) was swollen in
DCM for 30 min and then washed with DMF. Fmoc cleavage was carried out using $20 \%$ piperidine in DMF, at $\mathrm{rt}$ for $10 \mathrm{~min}$ $(\times 2)$. The resin was washed with DMF $(3 \times 5 \mathrm{~mL})$ and DCM $(3 \times 5 \mathrm{~mL})$. The coupling reaction was performed by adding to the resin a solution of the Fmoc-amino acid (1.5 mmol, 5 equiv), HATU (560 mg, $1.47 \mathrm{mmol}, 4.9$ equiv), DIPEA (0.51 $\mathrm{mL}, 3.0 \mathrm{mmol}, 10$ equiv) in DMF $(5 \mathrm{~mL})$, and the mixture was shaken for $2 \mathrm{~h}$. The coupling sequence was: $\mathrm{Fmoc}-\operatorname{Arg}(\mathrm{Pbf})-$ $\mathrm{OH}$, Fmoc-Gly-OH, Fmoc-Asn(Trt)-OH, Fmoc-Cys(Acm)$\mathrm{OH}$. Once the linear pentapeptide was assembled, the $\mathrm{N}$ terminal Fmoc protecting group vas removed. Cleavage of the pentapeptide from the resin and simultaneous removal of Trt and $\mathrm{Pbf}$ protecting groups was performed using a mixture of TFA/TIPS $/ \mathrm{H}_{2} \mathrm{O} 95: 2.5: 2.5 \mathrm{v} / \mathrm{v} / \mathrm{v}$ for $2 \mathrm{~h}$. The cleavage mixture was drained off and the resin washed with TFA and DCM. The mixture was concentrated and $\mathrm{Et}_{2} \mathrm{O}$ was added to precipitate the crude peptide. The crude linear peptide $(270 \mathrm{mg}, 0.30$ mmol, 1 equiv) was dissolved in $\mathrm{AcOH}(15 \mathrm{~mL})$ and added dropwise over $3 \mathrm{~h}$ to a solution of $\mathrm{I}_{2}(0.12 \mathrm{M})$ in $\mathrm{AcOH}(150$ $\mathrm{mL})$ and $\mathrm{HCl} 10 \mathrm{M}(1 \mathrm{~mL}){ }^{24}$ The cyclization reaction was monitored by RP-HPLC coupled to tandem ESI-MS and stopped after $2 \mathrm{~h}$ by adding $\mathrm{Et}_{2} \mathrm{O}$. The resulting suspension was cooled in dry ice and then centrifuged at $5000 \mathrm{rpm}$ for $3 \mathrm{~min}$, decanted, and the resulting white solid was purified by semipreparative RP-HPLC (Solvent A: $\mathrm{CH}_{3} \mathrm{CN} 0.1 \%$ TFA, Solvent B: $\mathrm{H}_{2} \mathrm{O} 0.1 \%$ TFA, gradient: from $1 \%$ to $7 \%$ of $\mathrm{A}$ in 8 $\mathrm{min}$, flow $5 \mathrm{~mL} / \mathrm{min}, t_{\mathrm{R}}=6 \mathrm{~min}$ ). The purified compound was lyophilized and obtained as a white powder $(35 \mathrm{mg}, 2 \cdot \mathrm{TFA}$ salt, $15 \%$ yield based on the estimated loading of the resin). ${ }^{1} \mathrm{H}$ $\operatorname{NMR}\left(400 \mathrm{MHz}, \mathrm{D}_{2} \mathrm{O}\right): \delta=4.92(\mathrm{t}, J=7.2 \mathrm{~Hz}, 1 \mathrm{H}), 4.64(\mathrm{dd}$, $J=9.9,3.5 \mathrm{~Hz}, 1 \mathrm{H}), 4.31(\mathrm{t}, J=7.3 \mathrm{~Hz}, 1 \mathrm{H}), 4.24-4.08(\mathrm{~m}$, $2 \mathrm{H}), 3.67(\mathrm{~d}, J=15.6 \mathrm{~Hz}, 1 \mathrm{H}), 3.40-3.26(\mathrm{~m}, 3 \mathrm{H}), 3.23(\mathrm{t}, J=$ $6.7 \mathrm{~Hz}, 2 \mathrm{H}), 3.12(\mathrm{dd}, J=14.4,9.9 \mathrm{~Hz}, 1 \mathrm{H}), 2.84$ (dd, $J=15.3$, $6.5 \mathrm{~Hz}, 1 \mathrm{H}), 2.72(\mathrm{dd}, J=15.5,8.0 \mathrm{~Hz}, 1 \mathrm{H}), 1.91-1.61(\mathrm{~m}$, $4 \mathrm{H}) .{ }^{13} \mathrm{C}$ NMR $\left(101 \mathrm{MHz}, \mathrm{D}_{2} \mathrm{O}\right.$, the signal of TFA was not included): $\delta=174.20,173.81,173.68,171.57,170.60,167.26$, $156.74,53.61,52.73$ (one signal for two carbons, as detected by HSQC analysis), 50.07, 42.43, 41.18, 40.49, 40.43, 36.14, 27.22, 24.21. MS (ESI, $m / z$ ): calculated for $\mathrm{C}_{18} \mathrm{H}_{31} \mathrm{~N}_{9} \mathrm{O}_{7} \mathrm{~S}_{2}$ 549.18; found $550.2[\mathrm{M}+\mathrm{H}]^{+}$. RP-HPLC: solvent A: $\mathrm{CH}_{3} \mathrm{CN} 0.1 \%$ TFA, Solvent B: $\mathrm{H}_{2} \mathrm{O} 0.1 \%$ TFA, gradient: from $1 \%$ to $15 \%$ of A in $15 \mathrm{~min}, t_{\mathrm{R}}=7.6 \mathrm{~min}$, flow: $1 \mathrm{~mL} / \mathrm{min}, \lambda=220 \mathrm{~nm}$.

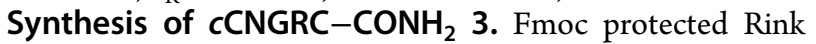
Amide MBHA resin HL (1.0 g, $0.87 \mathrm{mmol}$, loading: 0.87 $\mathrm{mmol} / \mathrm{g}$ ) was used for this synthesis. Swelling, Fmoc cleavage and washing procedures were performed as described above for compound 2. The coupling reactions were accomplished by adding to the resin a solution of the Fmoc-amino acid (1.74 mmol, 2 equiv), HATU (650 mg, $1.70 \mathrm{mmol}, 1.96$ equiv), DIPEA (0.6 mL, $3.48 \mathrm{mmol}, 4$ equiv) in DMF $(5 \mathrm{~mL})$ and shaking the mixture for $2 \mathrm{~h}$. The amino acid coupling sequence was as follows: Fmoc-Cys(Trt)-OH, Fmoc-Arg(Pbf)-OH, Fmoc-Gly-OH, Fmoc-Asn(Trt)-OH, and Fmoc-Cys(Trt)-OH. Cleavage of the pentapeptide from the resin and simultaneous removal of Trt and $\mathrm{Pbf}$ protecting groups was performed using a mixture of TFA/TIPS $/ \mathrm{H}_{2} \mathrm{O}$ 95:2.5:2.5 v/v/v for $2 \mathrm{~h}$. The mixture was concentrated and $\mathrm{Et}_{2} \mathrm{O}$ was added to precipitate the crude peptide. $\mathrm{N}$-Chlorosuccinimide $(60 \mathrm{mg}, 0.45 \mathrm{mmol}, 1$ equiv) was added to the solution of the crude linear peptide (350 mg, 2.TFA salt, $0.45 \mathrm{mmol}, 1$ equiv) in $\mathrm{H}_{2} \mathrm{O}(20 \mathrm{~mL})$ and the reaction was allowed to stir at room temperature for 15 min. The reaction mixture was then frozen in dry ice and freeze-dried to obtain the crude cyclic peptide as a white 
powder. The crude peptide was purified by semipreparative RPHPLC (Solvent A: $\mathrm{CH}_{3} \mathrm{CN} 0.1 \%$ TFA, Solvent B: $\mathrm{H}_{2} \mathrm{O} 0.1 \%$ TFA, gradient: from $1 \%$ to $7 \%$ of $A$ in $7 \mathrm{~min}$, flow: $5 \mathrm{~mL} / \mathrm{min}$, $\left.t_{\mathrm{R}}=6.2 \mathrm{~min}\right)$ and lyophilized to give compound 3 as a white powder $(170 \mathrm{mg}$, TFA salt, $25 \%$ yield based on the estimated loading of the resin). ${ }^{1} \mathrm{H}$ NMR $\left(400 \mathrm{MHz}, \mathrm{D}_{2} \mathrm{O}\right): \delta=4.92(\mathrm{t}, J$ $=7.3 \mathrm{~Hz}, 1 \mathrm{H}), 4.63(\mathrm{dd}, J=10.4,3.4 \mathrm{~Hz}, 1 \mathrm{H}), 4.31(\mathrm{t}, J=7.3$ $\mathrm{Hz}, 1 \mathrm{H}), 4.20-4.13(\mathrm{~m}, 2 \mathrm{H}), 3.67$ (d, $J=15.7 \mathrm{~Hz}, 1 \mathrm{H}), 3.38$ (dd, $J=14.5,6.8 \mathrm{~Hz}, 1 \mathrm{H}), 3.32(\mathrm{dd}, J=14.5,3.5 \mathrm{~Hz}, 1 \mathrm{H})$, $3.27-3.18(\mathrm{~m}, 3 \mathrm{H}), 3.05(\mathrm{dd}, J=14.5,10.4 \mathrm{~Hz}, 1 \mathrm{H}), 2.85(\mathrm{dd}$, $J=15.5,6.7 \mathrm{~Hz}, 1 \mathrm{H}), 2.73(\mathrm{dd}, J=15.5,7.9 \mathrm{~Hz}, 1 \mathrm{H}), 1.94-$ $1.57(\mathrm{~m}, 4 \mathrm{H}) .{ }^{13} \mathrm{C}$ NMR $\left(101 \mathrm{MHz}, \mathrm{D}_{2} \mathrm{O}\right.$, the signal of TFA was not included): $\delta=174.24,174.21,173.97,171.62,170.70$, 167.23, 156.74, 53.50, 52.84, 52.69, 50.08, 42.40, 41.18, 40.51, 40.44, 36.03, 27.04, 24.27. MS (ESI, $m / z$ ): calculated for $\mathrm{C}_{18} \mathrm{H}_{32} \mathrm{~N}_{10} \mathrm{O}_{6} \mathrm{~S}_{2}$ 548.19; found 549.2 [M+H $]^{+}$. RP-HPLC: solvent A: $\mathrm{CH}_{3} \mathrm{CN} 0.1 \%$ TFA, Solvent B: $\mathrm{H}_{2} \mathrm{O} 0.1 \%$ TFA, gradient: from $1 \%$ to $15 \%$ of $\mathrm{A}$ in $15 \mathrm{~min}, t_{\mathrm{R}}=8.0 \mathrm{~min}$, flow: 1 $\mathrm{mL} / \mathrm{min}, \lambda=220 \mathrm{~nm}$.

Synthesis of Ac-cCNGRC 4. The linear precursor 9 (Scheme 1) was assembled on the Fmoc-Cys (Acm) preloaded Wang resin (500 $\mathrm{mg}, 0.30 \mathrm{mmol}$, loading: $0.60 \mathrm{mmol} / \mathrm{g}$ ) following the procedure described for compound 2. After Fmoc cleavage from the last amino acid, acetylation of the $\mathrm{N}$-terminus was performed on-resin adding a solution of DCM/acetic anhydride/DIPEA 20:4:1 v/v/v $(8 \mathrm{~mL})$ and the resulting suspension was shaken for $1 \mathrm{~h}$ (repeated 2 times). Cleavage from the resin was carried out using a solution of TFA/TIPS/ $\mathrm{H}_{2} \mathrm{O}$ 95:2.5:2.5 v/v/v for $2 \mathrm{~h}$. The mixture was concentrated and $\mathrm{Et}_{2} \mathrm{O}$ was added to precipitate the crude peptide. Cyclization was performed following the procedure described for $2 .{ }^{24}$ The crude material was purified by semipreparative RPHPLC (Solvent A: $\mathrm{CH}_{3} \mathrm{CN} \mathrm{0.1 \%} \mathrm{TFA,} \mathrm{Solvent} \mathrm{B:} \mathrm{H}_{2} \mathrm{O} 0.1 \%$ TFA, gradient: from $10 \%$ to $15 \%$ of $\mathrm{A}$ in $7 \mathrm{~min}$, flow: $5 \mathrm{~mL} /$ $\min , t_{\mathrm{R}}=5.7 \mathrm{~min}$ ) and lyophilized to give compound 4 as a white powder $(65 \mathrm{mg}$, TFA salt, $30 \%$ yield based on the estimated loading of the resin). ${ }^{1} \mathrm{H} \mathrm{NMR}\left(400 \mathrm{MHz}, \mathrm{D}_{2} \mathrm{O}\right): \delta=$ $4.74(\mathrm{dd}, J=9.0,3.6 \mathrm{~Hz}, 1 \mathrm{H}), 4.65(\mathrm{t}, J=7.2 \mathrm{~Hz}, 1 \mathrm{H}), 4.49-$ $4.39(\mathrm{~m}, 2 \mathrm{H}), 4.22(\mathrm{~d}, J=16.4 \mathrm{~Hz}, 1 \mathrm{H}), 3.73(\mathrm{~d}, J=16.4 \mathrm{~Hz}$, $1 \mathrm{H}), 3.33$ (dd, $J=15.3,4.4 \mathrm{~Hz}, 1 \mathrm{H}), 3.25(\mathrm{t}, J=6.6 \mathrm{~Hz}, 2 \mathrm{H})$, $3.21-3.18(\mathrm{~m}, 1 \mathrm{H}), 3.15(\mathrm{dd}, J=7.3,3.8 \mathrm{~Hz}, 2 \mathrm{H}), 2.93(\mathrm{dd}, J=$ 15.4, $6.6 \mathrm{~Hz}, 1 \mathrm{H}), 2.71(\mathrm{dd}, J=15.4,7.7 \mathrm{~Hz}, 1 \mathrm{H}), 2.05(\mathrm{~s}, 3 \mathrm{H})$, 2.00-1.62 (m, 4H). ${ }^{13} \mathrm{C}$ NMR $\left(101 \mathrm{MHz}, \mathrm{D}_{2} \mathrm{O}\right.$, the signal of TFA was not included): $\delta=174.78,174.39,173.51,173.41$, $172.18,172.02,171.24,156.73,53.69,53.39,52.60,50.61$, 42.60, 40.96, 40.54, 40.47, 35.57, 27.59, 24.31, 21.74. MS (ESI, $m / z)$ : calculated for $\mathrm{C}_{20} \mathrm{H}_{33} \mathrm{~N}_{9} \mathrm{O}_{8} \mathrm{~S}_{2} 591.19$ found $592.2[\mathrm{M}+$ $\mathrm{H}]^{+}$. RP-HPLC: solvent A: $\mathrm{CH}_{3} \mathrm{CN} 0.1 \%$ TFA, Solvent B: $\mathrm{H}_{2} \mathrm{O}$ $0.1 \%$ TFA, gradient: from $10 \%$ to $25 \%$ of $\mathrm{A}$ in $11 \mathrm{~min} t_{\mathrm{R}}=6.7$ min, flow $1 \mathrm{~mL} / \mathrm{min}, \lambda=220 \mathrm{~nm}$.

Synthesis of Biotin- $\boldsymbol{\varepsilon}$-Ahx-cCNGRC 5. The linear precursor 9 (Scheme 1) was assembled on the FmocCys (Acm) preloaded Wang resin (100-200 mesh, $200 \mathrm{mg}$, $0.14 \mathrm{mmol}$, loading: $0.70 \mathrm{mmol} / \mathrm{g}$ ) following the procedure described for compound 2. After Fmoc cleavage from the last amino acid, a solution of Fmoc- $\varepsilon$-Ahx-OH $(250 \mathrm{mg}, 0.70 \mathrm{mmol}$, 5 equiv), DIC ( $0.11 \mathrm{~mL}, 0.70 \mathrm{mmol}, 5$ equiv), and Oxyma Pure Novabiochem ( $100 \mathrm{mg}, 0.70 \mathrm{mmol}, 5$ equiv) in DMF $(3 \mathrm{~mL})$ was added and the suspension was shaken for $2 \mathrm{~h}$. Then, the $N$ terminal Fmoc protecting group was removed. The cyclization step was carried out on resin by adding to the resin a solution of $\mathrm{I}_{2}$ (350 mg, $1.4 \mathrm{mmol}, 10$ equiv) in DMF/ $\mathrm{H}_{2} \mathrm{O} 4 / 1$ (v/v) (3 $\mathrm{mL})$. After $4 \mathrm{~h}$ the solvent was removed and the resin was extensively washed with DMF $(2 \times 5 \mathrm{~mL}), 2 \%$ ascorbic acid in DMF $(2 \times 5 \mathrm{~mL}), \operatorname{DMF}(5 \times 5 \mathrm{~mL})$, and DCM $(3 \times 5 \mathrm{~mL})$. Biotin $(340 \mathrm{mg}, 1.4 \mathrm{mmol}, 10$ equiv), DIC $(0.22 \mathrm{~mL}, 1.4 \mathrm{mmol}$, 10 equiv), and Oxyma Pure Novabiochem (200 mg, $1.4 \mathrm{mmol}$, 10 equiv) were suspended in DMF $(14 \mathrm{~mL})$ at $60{ }^{\circ} \mathrm{C}$ and stirred for about $40 \mathrm{~min}$ until the activated biotin was completely dissolved. After cooling to room temperature, the reaction mixture was added to the cyclic peptide-resin and shaken for $24 \mathrm{~h}$. The resin was washed with DCM $(5 \times 10 \mathrm{~mL})$ and DMF $(5 \times 10 \mathrm{~mL})$. Biotin-labeled cyclic peptide was cleaved from the resin, along with the deprotection of the amino acid side chains by adding a mixture of TFA/TIPS $/ \mathrm{H}_{2} \mathrm{O}$ $95 / 2.5 / 2.5(\mathrm{v} / \mathrm{v} / \mathrm{v})$ for $2 \mathrm{~h}$. The mixture was concentrated and $\mathrm{Et}_{2} \mathrm{O}$ was added to precipitate the crude peptide. The crude was dissolved in $\mathrm{H}_{2} \mathrm{O}$, purified by semipreparative RP-HPLC (Solvent A: $\mathrm{CH}_{3} \mathrm{CN} \mathrm{0.1 \%} \mathrm{TFA,} \mathrm{Solvent} \mathrm{B:} \mathrm{H}_{2} \mathrm{O} 0.1 \%$ TFA, gradient: from $10 \%$ to $35 \%$ of $\mathrm{A}$ in $15 \mathrm{~min}$, flow $5 \mathrm{~mL} / \mathrm{min}, t_{\mathrm{R}}=$ $7 \mathrm{~min}$ ) and lyophilized to give compound $\mathbf{5}$ as a white powder (9.6 mg, TFA salt, $7 \%$ yield based on estimated loading of the resin). ${ }^{1} \mathrm{H}$ NMR (400 MHz, $\left.\mathrm{D}_{2} \mathrm{O}\right): \delta=4.66-4.57(\mathrm{~m}, 2 \mathrm{H})$, $4.50(\mathrm{dd}, J=8.4,5.9 \mathrm{~Hz}, 1 \mathrm{H}), 4.46-4.35(\mathrm{~m}, 2 \mathrm{H}), 4.22(\mathrm{~d}, J=$ $16.3 \mathrm{~Hz}, 1 \mathrm{H}), 4.00-3.96(\mathrm{~m}, 1 \mathrm{H}), 3.72(\mathrm{~d}, J=16.4 \mathrm{~Hz}, 1 \mathrm{H})$, 3.39-2.77 (m, 12H), $2.71(\mathrm{dd}, J=15.5,7.5 \mathrm{~Hz}, 1 \mathrm{H}), 2.40-$ $2.23(\mathrm{~m}, 4 \mathrm{H}), 1.96-1.30(\mathrm{~m}, 16 \mathrm{H})$. MS (ESI, $m / z)$ : calculated for $\mathrm{C}_{34} \mathrm{H}_{56} \mathrm{~N}_{12} \mathrm{O}_{10} \mathrm{~S}_{3}$ 888.34; found $889.3[\mathrm{M}+\mathrm{H}]^{+}$. RP-HPLC: solvent A: $\mathrm{CH}_{3} \mathrm{CN} 0.1 \%$ TFA, Solvent B: $\mathrm{H}_{2} \mathrm{O} 0.1 \%$ TFA, gradient: from $5 \%$ to $50 \%$ of $A$ in $15 \mathrm{~min}, t_{\mathrm{R}}=10.46 \mathrm{~min}$, flow: $1 \mathrm{~mL} / \mathrm{min}, \lambda=220 \mathrm{~nm}$.

Synthesis of cCNGRCKG-biotin 6. The linear peptide 11 was assembled on an Fmoc protected Rink Amide MBHA resin HL (1.0 g, $0.87 \mathrm{mmol}$, loading: $0.87 \mathrm{mmol} / \mathrm{g}$ ) following the procedure already described for compound 3 . The amino acid coupling sequence was Fmoc-Gly-OH, Fmoc-Lys(Dde)-OH, Fmoc-Cys(Mmt)-OH, Fmoc-Arg(Pbf)-OH, Fmoc-Gly-OH, Fmoc-Asn(Trt)-OH, Boc-Cys(Mmt)-OH. Once the linear heptapeptide 11 was assembled, Dde removal was achieved using a solution $(10 \mathrm{~mL})$ of $\mathrm{NH}_{2} \mathrm{NH}_{2}(2 \%)$ in DMF for $3 \mathrm{~min}$ $(\times 2)$. Biotin (420 mg, $1.74 \mathrm{mmol}, 2$ equiv) was dissolved in DMF $(8 \mathrm{~mL})$ and the solution warmed at $80{ }^{\circ} \mathrm{C}$ in order to solubilize the solid powder. Once biotin was completely solubilized, the mixture was cooled to rt before adding HATU (650 mg, $1.70 \mathrm{mmol}, 1.96$ equiv) and DIPEA (0.6 $\mathrm{mL}, 3.48 \mathrm{mmol}, 4$ equiv). The mixture was added to the resin and the suspension was shaken for $2 \mathrm{~h}$. The coupling was repeated two times. Cleavage of the biotin labeled peptide 12 from the resin and simultaneous removal of $\mathrm{Mmt}$, Trt, and $\mathrm{Pbf}$ protecting groups was performed using a mixture of TFA/ TIPS $/ \mathrm{H}_{2} \mathrm{O}$ 95:2.5:2.5 v/v/v for $2 \mathrm{~h}$. The mixture was concentrated and $\mathrm{Et}_{2} \mathrm{O}$ was added to precipitate the crude peptide. The crude peptide $(860 \mathrm{mg}, 0.72 \mathrm{mmol}$ ) was dissolved in $50 \mathrm{mM}$ phosphate buffer, $\mathrm{pH} 7.4(250 \mathrm{~mL})$ and the reaction was stirred while bubbling air through it. The disulfide bridge formation was monitored by RP-HPLC coupled to tandem ESI-MS and it was complete after $72 \mathrm{~h}$. The aqueous medium was concentrated under reduced pressure and the resulting precipitate was filtered and washed several times with $\mathrm{H}_{2} \mathrm{O}$ and $\mathrm{CH}_{3} \mathrm{CN}$. Compound 6 was obtained as a pure white powder $400 \mathrm{mg}, 48 \%$ yield, based on the estimated loading of the resin). ${ }^{1} \mathrm{H}$ NMR (400 MHz, $\mathrm{D}_{2} \mathrm{O}$ ): $\delta=4.79$ (overlapped with solvent signal as detected by COSY and HSQC experiments, $1 \mathrm{H}) 4.66-4.59(\mathrm{~m}, 2 \mathrm{H}), 4.44(\mathrm{dd}, J=7.7,4.5 \mathrm{~Hz}, 1 \mathrm{H}), 4.40-$ $4.34(\mathrm{~m}, 1 \mathrm{H}), 4.31$ (dd, $J=8.4,5.5 \mathrm{~Hz}, 1 \mathrm{H}), 4.15$ (d, $J=16.0$ $\mathrm{Hz}, 1 \mathrm{H}), 3.96(\mathrm{~d}, J=17.1 \mathrm{~Hz}, 1 \mathrm{H}), 3.90(\mathrm{~d}, J=17.1 \mathrm{~Hz}, 1 \mathrm{H})$, 
$3.75(\mathrm{~d}, J=16.2 \mathrm{~Hz}, 1 \mathrm{H}), 3.70($ brs, $1 \mathrm{H}), 3.40-2.73(\mathrm{~m}, 13 \mathrm{H})$, $2.27(\mathrm{t}, J=7.0 \mathrm{~Hz}, 2 \mathrm{H}), 1.96-1.30(\mathrm{~m}, 16 \mathrm{H})$. MS (ESI, $m / z)$ : calculated for $\mathrm{C}_{36} \mathrm{H}_{61} \mathrm{~N}_{15} \mathrm{O}_{10} \mathrm{~S}_{3}$ 959.39; found ESI-MS: $\mathrm{m} / z$ $960.3[\mathrm{M}+\mathrm{H}]^{+}$. RP-HPLC: solvent A: $\mathrm{CH}_{3} \mathrm{CN} 0.1 \%$ TFA, Solvent B: $\mathrm{H}_{2} \mathrm{O} 0.1 \%$ TFA, gradient: from $5 \%$ to $40 \%$ of $\mathrm{A}$ in $11 \mathrm{~min}, t_{\mathrm{R}}=8.2 \mathrm{~min}$, flow: $1 \mathrm{~mL} / \mathrm{min}, \lambda=220 \mathrm{~nm}$.

Synthesis of Ac-cCNGRCKG-biotin 7. Compound 6 (15 $\mathrm{mg}, 15.6 \mu \mathrm{mol}, 1$ equiv) was dissolved in water $(2.5 \mathrm{~mL})$ and treated with acetic anhydride $(5.0 \mu \mathrm{L}, 52.9 \mu \mathrm{mol}, 3.4$ equiv $)$ at rt for $10 \mathrm{~min}$. The crude peptide was purified by semipreparative RP-HPLC (Solvent A: $\mathrm{CH}_{3} \mathrm{CN} 0.1 \%$ TFA, Solvent B: $\mathrm{H}_{2} \mathrm{O} 0.1 \%$ TFA, gradient: from $5 \%$ to $50 \%$ of $\mathrm{A}$ in $15 \mathrm{~min}$, flow: $5 \mathrm{~mL} / \mathrm{min}, t_{\mathrm{R}}=10.8 \mathrm{~min}$ ) and lyophilized to give compound 7 as a white powder $\left(17 \mathrm{mg}\right.$, quantitative yield). ${ }^{1} \mathrm{H}$ NMR (400 MHz, $\left.\mathrm{D}_{2} \mathrm{O}\right): \delta=4.70-4.61(\mathrm{~m}, 3 \mathrm{H}), 4.52(\mathrm{t}, J=$ $7.1 \mathrm{~Hz}, 1 \mathrm{H}), 4.46-4.38(\mathrm{~m}, 2 \mathrm{H}), 4.31(\mathrm{dd}, J=8.7,5.5 \mathrm{~Hz}, 1 \mathrm{H})$, $4.20(\mathrm{~d}, J=16.4 \mathrm{~Hz}, 1 \mathrm{H}), 3.96(\mathrm{~d}, J=17.2 \mathrm{~Hz}, 1 \mathrm{H}), 3.89$ (d, $J$ $=17.3 \mathrm{~Hz}, 1 \mathrm{H}), 3.73(\mathrm{~d}, J=16.3 \mathrm{~Hz}, 1 \mathrm{H}), 3.38-3.09(\mathrm{~m}, 9 \mathrm{H})$, $3.01(\mathrm{dd}, J=13.0,4.9 \mathrm{~Hz}, 1 \mathrm{H}), 2.93(\mathrm{dd}, J=15.5,6.5 \mathrm{~Hz}, 1 \mathrm{H})$, $2.83-2.70(\mathrm{~m}, 2 \mathrm{H}), 2.27(\mathrm{t}, J=7.1 \mathrm{~Hz}, 2 \mathrm{H}), 2.06(\mathrm{~s}, 3 \mathrm{H})$, $1.95-1.36(\mathrm{~m}, 16 \mathrm{H}) .{ }^{13} \mathrm{C}$ NMR $\left(101 \mathrm{MHz}, \mathrm{D}_{2} \mathrm{O}\right): \delta=176.63$, 174.66, 174.27, 174.25, 173.90, 173.59, 172.11, 171.89, 171.79, $171.44,165.30,156.71,62.10,60.25,55.46,54.03,53.45,53.42$, $53.20,50.50,42.76,42.03,40.99,40.53,40.33,39.70,38.92$, $35.64,35.46,30.33,27.87,27.80,27.67,27.51,25.17,24.40$, 22.45, 21.73. MS (ESI, $m / z$ ): calculated for $\mathrm{C}_{38} \mathrm{H}_{63} \mathrm{~N}_{15} \mathrm{O}_{11} \mathrm{~S}_{3}$ 1001.4; found 1002.4 $[\mathrm{M}+\mathrm{H}]^{+}$. RP-HPLC: solvent A: $\mathrm{CH}_{3} \mathrm{CN}$ $0.1 \%$ TFA, Solvent B: $\mathrm{H}_{2} \mathrm{O} 0.1 \%$ TFA, gradient: from $5 \%$ to $50 \%$ of $\mathrm{A}$ in $15 \mathrm{~min}, t_{\mathrm{R}}=10.5 \mathrm{~min}$, flow: $1 \mathrm{~mL} / \mathrm{min}, \lambda=220$ $\mathrm{nm}$.

Synthesis of 5(6)-Carboxy-2', $\mathbf{7}^{\prime}$-difluorofluorescein (Oregon green 488). ${ }^{19}$ Trimetillic anhydride $(750 \mathrm{mg}, 3.9$ mmol, 1 equiv) was added to a $1 \mathrm{M}$ solution of 4Fluororesorcinol (1 g, $7.8 \mathrm{mmol}, 2$ equiv) in methanesulfonic acid $(7.8 \mathrm{~mL})$. The resulting mixture was heated under dry nitrogen at $80^{\circ} \mathrm{C}$ for $24 \mathrm{~h}$. The cooled mixture was poured into 7 volumes of ice water and the resulting precipitate was filtrated, washed with $\mathrm{H}_{2} \mathrm{O}$, and dried at $60^{\circ} \mathrm{C}$ to give $5(6)$ carboxy-2 $2^{\prime}, 7^{\prime}$-difluorofluorescein as an orange powder $(1.6 \mathrm{~g}$, quantitative yield). ${ }^{1} \mathrm{H}$ NMR (400 MHz, MeOD) $\delta 8.64$ (s, $1 \mathrm{H}), 8.42$ (dd, $J=8.0,1.5 \mathrm{~Hz}, 1 \mathrm{H}), 8.35(\mathrm{dd} J=8.0,1.3 \mathrm{~Hz}$, $1 \mathrm{H}), 8.14(\mathrm{~d}, J=7.7 \mathrm{~Hz}, 1 \mathrm{H}), 7.79(\mathrm{~s}, 1 \mathrm{H}), 7.36(\mathrm{~d}, J=8.0 \mathrm{~Hz}$, $1 \mathrm{H}), 6.90-6.85(\mathrm{~m}, 4 \mathrm{H}), 6.46(\mathrm{~d}, J=10.2 \mathrm{~Hz}, 4 \mathrm{H}) .{ }^{19} \mathrm{~F}$ NMR $\left(376 \mathrm{MHz}, \mathrm{DMSO}-d_{6}\right) \delta-139.69,-139.73$.

Synthesis of cCNGRCKG-OG 8. NovaPEG Rink Amide resin $(1.0 \mathrm{~g}$, $0.49 \mathrm{mmol}$, loading: $0.49 \mathrm{mmol} / \mathrm{g})$ was used for the synthesis of the linear peptide 11. Swelling, Fmoc cleavage, and washing of the resin were performed as described for compound 2 . The coupling reaction was performed by adding to the resin a solution of the Fmoc-aa ( $2.45 \mathrm{mmol}, 5$ equiv), HATU (913 mg, $2.4 \mathrm{mmol}, 4.9$ equiv), DIPEA (0.8 mL, 4.9 mmol, 10 equiv) in DMF ( $5 \mathrm{~mL})$, and the mixture was shaken for $2 \mathrm{~h}$. The amino acid coupling sequence was Fmoc-Gly-OH, Fmoc-Lys(Dde)-OH, Fmoc-Cys(Mmt)-OH, Fmoc-Arg(Pbf)$\mathrm{OH}$, Fmoc-Gly-OH, Fmoc-Asn(Trt)-OH, Boc-Cys(Mmt)-OH. After assembling the linear peptide, the Dde removal was achieved as described for compound 6 and the fluorescent probe OG (synthesized as a mixture of 5 and 6 regioisomers according to ref 19) was then coupled by adding to the resin the solution of OG ( $400 \mathrm{mg}, 0.98 \mathrm{mmol}, 2$ equiv), HATU (365 mg; $0.96 \mathrm{mmol}, 1.96$ equiv), and DIPEA (0.33 mL, $1.96 \mathrm{mmol}$, 4 equiv) in DMF $(6 \mathrm{~mL})$ and the resulting red suspension was shaken for $2 \mathrm{~h}$. The resin was extensively washed with DMF (3 $\times 5 \mathrm{~mL}), \mathrm{DCM}(3 \times 5 \mathrm{~mL})$, and $\mathrm{MeOH}$ containing $0.1 \%$ $\mathrm{NH}_{4} \mathrm{OH}$ conc. $(10 \times 5 \mathrm{~mL})$. Cleavage of the OG labeled peptide 13 from the resin and simultaneous removal of $\mathrm{Mmt}$, Trt, and $\mathrm{Pbf}$ protecting groups were performed using a mixture of TFA/TIPS $/ \mathrm{H}_{2} \mathrm{O}$ 95:2.5:2.5 v/v/v for $2 \mathrm{~h}$. The mixture was concentrated and $\mathrm{Et}_{2} \mathrm{O}$ was added to precipitate the crude peptide. $\mathrm{N}$-Chlorosuccinimide ( $53 \mathrm{mg}, 0.4 \mathrm{mmol}$, 1 equiv) was added to the solution of the crude linear peptide $(540 \mathrm{mg}$, TFA salt, 0.4 mmol, 1 equiv) in $\mathrm{H}_{2} \mathrm{O} / \mathrm{CH}_{3} \mathrm{CN} 9: 1(40 \mathrm{~mL})$ and the reaction was allowed to stir at room temperature for $15 \mathrm{~min}$. The reaction mixture was then frozen in dry ice and freezedried to obtain the crude cyclic peptide as an orange powder. The crude peptide was purified by semipreparative RP-HPLC (Solvent A: $\mathrm{CH}_{3} \mathrm{CN} \mathrm{0.1 \%} \mathrm{TFA,} \mathrm{Solvent} \mathrm{B:} \mathrm{H}_{2} \mathrm{O} 0.1 \%$ TFA, gradient: $26 \%$ of $A$ in $7 \mathrm{~min}$, flow: $5 \mathrm{~mL} / \mathrm{min}$, isomer $\mathrm{A}, t_{\mathrm{R}}=5.6$ min; isomer $\mathrm{B}, t_{\mathrm{R}}=6.1 \mathrm{~min}$ ) and lyophilized to give compound 8 isomer $\mathrm{A}$ and isomer $\mathrm{B}$ as an orange powder $(180 \mathrm{mg}$, TFA salt, $25 \%$ yield based on the estimated loading of the resin). Isomer (A): ${ }^{1} \mathrm{H}$ NMR (400 MHz, $\left.\mathrm{D}_{2} \mathrm{O}\right) \delta=8.45(\mathrm{~s}, 1 \mathrm{H})$, 8.10-8.03 (m, 1H), 7.34-7.25 (m, 1H), 6.82-6.75 (m, 2H), $6.67-6.56(\mathrm{~m}, 2 \mathrm{H}), 4.91(\mathrm{t}, J=7.1 \mathrm{~Hz}, 1 \mathrm{H}), 4.60(\mathrm{dd}, J=8.9$, $2.8 \mathrm{~Hz}, 1 \mathrm{H}), 4.40-4.31(\mathrm{~m}, 1 \mathrm{H}), 4.26-4.16(\mathrm{~m}, 2 \mathrm{H}), 4.11(\mathrm{~d}, J$ $=15.8 \mathrm{~Hz}, 1 \mathrm{H}), 3.95(\mathrm{~d}, J=17.6 \mathrm{~Hz}, 1 \mathrm{H}), 3.88(\mathrm{~d}, J=17.2 \mathrm{~Hz}$, $1 \mathrm{H}), 3.65(\mathrm{~d}, J=15.6 \mathrm{~Hz}, 1 \mathrm{H}), 3.47-2.98(\mathrm{~m}, 8 \mathrm{H}), 2.83(\mathrm{dd}, J$ $=15.3,6.3 \mathrm{~Hz}, 1 \mathrm{H}), 2.73(\mathrm{dd}, J=15.5,7.7 \mathrm{~Hz}, 1 \mathrm{H}), 1.98-$ $-1.36(\mathrm{~m}, 10 \mathrm{H}) .{ }^{19} \mathrm{~F}$ NMR $\left(376 \mathrm{MHz}, \mathrm{D}_{2} \mathrm{O}\right) \delta=-75.55$ (TFA signal), -134.87. Isomer (B): ${ }^{1} \mathrm{H}$ NMR (400 MHz, $\left.\mathrm{D}_{2} \mathrm{O}\right) \delta=$ $8.10(\mathrm{~d}, J=6.8 \mathrm{~Hz}, 1 \mathrm{H}), 7.96(\mathrm{~d}, J=6.5 \mathrm{~Hz}, 1 \mathrm{H}), 7.54(\mathrm{~s}, 1 \mathrm{H})$, 6.80-6.77 (m, 2H), $6.56(\mathrm{~s}, 2 \mathrm{H}), 4.91(\mathrm{t}, J=7.1 \mathrm{~Hz}, 1 \mathrm{H}), 4.58$ (dd, $J=9.1,3.6 \mathrm{~Hz}, 1 \mathrm{H}), 4.27-4.16(\mathrm{~m}, 3 \mathrm{H}), 4.11(\mathrm{~d}, J=15.7$ $\mathrm{Hz}, 1 \mathrm{H}), 3.91(\mathrm{~d}, J=17.2 \mathrm{~Hz}, 1 \mathrm{H}), 3.84(\mathrm{~d}, J=17.2 \mathrm{~Hz}, 1 \mathrm{H})$, $3.65(\mathrm{~d}, J=15.7 \mathrm{~Hz}, 1 \mathrm{H}), 3.40-2.98(\mathrm{~m}, 8 \mathrm{H}), 2.84(\mathrm{dd}, J=$ 15.6, $6.4 \mathrm{~Hz}, 1 \mathrm{H}), 2.73(\mathrm{dd} J=15.5,7.8 \mathrm{~Hz}, 1 \mathrm{H}), 1.82-1.26$ $(\mathrm{m}, 10 \mathrm{H}) .{ }^{19} \mathrm{~F}$ NMR $\left(376 \mathrm{MHz}, \mathrm{D}_{2} \mathrm{O}\right) \delta=-75.55$ (TFA signal), -134.87. MS (ESI, $m / z)$ : calculated for $\mathrm{C}_{47} \mathrm{H}_{55} \mathrm{~F}_{2} \mathrm{~N}_{13} \mathrm{O}_{14} \mathrm{~S}_{2}$ 1127.3; found 1128.4 [M+H] $]^{+}$. RPHPLC: solvent A: $\mathrm{CH}_{3} \mathrm{CN}$ 0.1\% TFA, Solvent B: $\mathrm{H}_{2} \mathrm{O} 0.1 \%$ TFA, gradient: from $10 \%$ to $60 \%$ of $\mathrm{A}$ in $15 \mathrm{~min}$, isomer $\mathrm{A}, t_{\mathrm{R}}=$ $9.9 \mathrm{~min}$; isomer $\mathrm{B}, t_{\mathrm{R}}=10.2 \mathrm{~min}$, flow: $1 \mathrm{~mL} / \mathrm{min}, \lambda=480 \mathrm{~nm}$.

In Vitro APN Inhibition Assay. $\mathrm{IC}_{50}$ values against $\mathrm{APN}$ were determined as previously described ${ }^{12,20,21}$ using L-leucine$p$-nitroanilide as substrate and microsomal aminopeptidase from porcine kidney ( $p$ APN, Sigma) (15 units/mg protein). The assay was performed in a 96-well plate in Phosphate Buffer Saline (PBS, $\mathrm{KH}_{2} \mathrm{PO}_{4} 1.47 \mathrm{mM}, \mathrm{Na}_{2} \mathrm{HPO}_{4} 7.8 \mathrm{mM}, \mathrm{NaCl} 137$ $\mathrm{mM}$, $\mathrm{KCl} 2.7 \mathrm{mM}, \mathrm{CaCl}_{2} 1.8 \mathrm{mM}, \mathrm{MgCl}_{2} 1.8 \mathrm{mM}$ ), pH 7.2, at $37^{\circ} \mathrm{C}$. Bestatin was used as a positive control, while biotin was used as a negative one. $0.5 \mu \mathrm{g} / \mathrm{mL}$ pAPN and $250 \mu \mathrm{M} \mathrm{L}-$ leucine- $p$-nitroanilide were incubated in $100 \mu \mathrm{L}$ of $\mathrm{PBS}, \mathrm{pH} 7.2$ in the presence of gradient concentrations of inhibitor (the concentration of peptides $2-7$ and biotin ranged from $5 \mu \mathrm{M}$ to $2.5 \mathrm{mM}$, while the concentration of bestatin 1 from $50 \mathrm{nM}$ to $25 \mu \mathrm{M})$. The assay mixture was incubated at $37{ }^{\circ} \mathrm{C}$ for $1 \mathrm{~h}$. Formation of the product $p$-nitroaniline was monitored by following the change in the absorbance measured at $405 \mathrm{~nm}$ with the UV-vis spectrophotometer (Synergy HT, BioTek). The $\mathrm{IC}_{50}$ value was defined as the concentration of each peptide that led to $50 \%$ of maximal pAPN catalytic activity.

Cell Culture. Human fibrosarcoma HT1080 cells were cultured in Dulbecco's Modified Essential Medium (Invitrogen) containing 9\% fetal bovine serum (SIGMA) and incubated at $37{ }^{\circ} \mathrm{C}$ in a humidified atmosphere containing $5 \% \mathrm{CO}_{2}$ and passed twice a week. 
Inhibitory Assay on HT1080 Cells. One day prior to the experiment, HT 1080 cells from a confluent plate were detached using trypsin/EDTA (Invitrogen) and plated at a $70 \%$ confluency in 96 well plate (approximately 60000 cell/well). $24 \mathrm{~h}$ later the cells were washed twice in PBS and incubated in $100 \mu \mathrm{L}$ of PBS containing $250 \mu \mathrm{M}$ APN substrate (L-leucine- $p$ nitroanilide) and the different compounds at the indicated concentration. The cells were then incubated for $1.5 \mathrm{~h}$ at $37^{\circ} \mathrm{C}$ and absorbance at $405 \mathrm{~nm}$ measured every $10 \mathrm{~min}$.

Binding Curve of Fluorescent CCNGRCKG-OG 8 on HT1080 Cells. One day prior to the experiment, HT1080 cells from a confluent plate were detached using trypsin/EDTA (Invitrogen) and plated at a 20\% confluency in 96 well plate (approximately 20000 cell/well). After $24 \mathrm{~h}$ the cells were incubated for $60 \mathrm{~min}$ on ice with increasing concentration of compound 8. After incubation the cells were washed three times in PBS and fixed in paraformaldehyde (3.7\% in PBS) for $15 \mathrm{~min}$, washed three times in PBS, and imaged at 20x magnification. For each field both a DIC and a fluorescent channel were collected.

Displacement of Fluorescent cCNGRCKG-OG 8 on HT1080 Cells. One day prior to the experiment, HT1080 cells from a confluent plate were detached using trypsin/EDTA (Invitrogen) and plated at a $20 \%$ confluency on glass coverslips (approximately 20000 cell/well). After $24 \mathrm{~h}$ the cells were incubated for $60 \mathrm{~min}$ on ice with compound $8(40 \mu \mathrm{M})$ in the absence or in the presence of bestatin $(100 \mu \mathrm{M})$ or compound $6(1 \mathrm{mM})$. After incubation the cells were washed three times in PBS and fixed in paraformaldehyde (3.7\% in PBS) for 15 min, washed three times in PBS, and imaged at $40 \times$ magnification. For each field both a DIC and a fluorescent channel were collected.

Quantification of Fluorescence on Cells. The microscopic fields were acquired using the same settings and exposure time for all the images and we ensured that all the pixels in the images were in the dynamic range of the detector (saturated pixels $<0.1 \%$ ). The images were then analyzed using ImageJ open source software. The outline of the cells were manually traced using the DIC channel. The outlines of the cells were then superimposed to the fluorescent channel and the fluorescence of each single cell was measured. For each condition we measured at least 120 cells.

\section{ASSOCIATED CONTENT}

\section{S Supporting Information}

The Supporting Information is available free of charge on the ACS Publications website at DOI: 10.1021/acs.bioconjchem.6b00136.

$$
\text { NMR spectra and HPLC chromatograms (PDF) }
$$

\section{AUTHOR INFORMATION}

\section{Corresponding Authors}

*E-mail: massimiliano.baldassarre@abdn.ac.uk. Telephone: +44 (0)1224 437572 .

*E-mail: monica.piras@abdn.ac.uk.

Notes

The authors declare no competing financial interest.

\section{ACKNOWLEDGMENTS}

We thank The Development Trust, University of Aberdeen, for financial support and a fellowship to M.P.

\section{ABBREVIATIONS}

Dde, $N$-(1-(4,4-dimethyl-2,6-dioxocyclohexylidene)ethyl); Acm, acetamidomethyl; Pbf, 2,2,4,6,7-pentamethyldihydrobenzofurane; Trt, trityl; Mmt, 4-methoxyphenyl)diphenylmethyl; Fmoc, Fluorenylmethyloxycarbonyl; APN, aminopeptidase N

\section{REFERENCES}

(1) Mina-Osorio, P. (2008) The moonlighting enzyme CD13: old and new functions to target. Trends Mol. Med. 14, 361-371.

(2) Guzman-Rojas, L., Rangel, R., Salameh, A., Edwards, J. K., Dondossola, E., Kim, Y.-G., Saghatelian, A., Giordano, R. J., Kolonin, M. G., Staquicini, F. I., et al. (2012) Cooperative effects of aminopeptidase N (CD13) expressed by nonmalignant and cancer cells within the tumor microenvironment. Proc. Natl. Acad. Sci. U. S. A. 109, 1637-1642.

(3) Wickström, M., Larsson, R., Nygren, P., and Gullbo, J. (2011) Aminopeptidase $\mathrm{N}$ (CD13) as a target for cancer chemotherapy. Cancer Sci. 102, 501-508.

(4) Arap, W., Pasqualini, R., and Ruoslahti, E. (1998) Cancer Treatment by Targeted Drug Delivery to Tumor Vasculature in a Mouse Model. Science 279, 377-380.

(5) Pasqualini, R., Koivunen, E., Kain, R., Lahdenranta, J., Sakamoto, M., Stryhn, A., Ashmun, R. A., Shapiro, L. H., Arap, W., and Ruoslahti, E. (2000) Aminopeptidase $\mathrm{N}$ is a receptor for tumor-homing peptides and a target for inhibiting angiogenesis. Cancer Res. 60, 722-727.

(6) Curnis, F., Sacchi, A., Borgna, L., Magni, F., Gasparri, A., and Corti, A. (2000) Enhancement of tumor necrosis factor alpha antitumor immunotherapeutic properties by targeted delivery to aminopeptidase N (CD13). Nat. Biotechnol. 18, 1185-1190.

(7) Gregorc, V., Zucali, P. A., Santoro, A., Ceresoli, G. L., Citterio, G., de Pas, T. M., Zilembo, N., de Vincenzo, F., Simonelli, M., Rossoni, G., et al. (2010) Phase II Study of Asparagine-Glycine-Arginine-Human Tumor Necrosis Factor $\alpha$, a Selective Vascular Targeting Agent, in Previously Treated Patients With Malignant Pleural Mesothelioma. J. Clin. Oncol. 28, 2604-2611.

(8) Von Wallbrunn, A., Waldeck, J., Höltke, C., Zühlsdorf, M., Mesters, R., Heindel, W., Schäfers, M., and Bremer, C. (2008) In vivo optical imaging of CD13/APN-expression in tumor xenografts. $J$. Biomed. Opt. 13, 011007.

(9) Oostendorp, M., Douma, K., Hackeng, T. M., Dirksen, A., Post, M. J., van Zandvoort, M. A. M. J., van, and Backes, W. H. (2008) Quantitative Molecular Magnetic Resonance Imaging of Tumor Angiogenesis Using cNGR-Labeled Paramagnetic Quantum Dots. Cancer Res. 68, 7676-7683.

(10) Chen, K., Ma, W., Li, G., Wang, J., Yang, W., Yap, L.-P., Hughes, L. D., Park, R, and Conti, P. S. (2013) Synthesis and evaluation of 64Cu-labeled monomeric and dimeric NGR peptides for MicroPET imaging of CD13 receptor expression. Mol. Pharmaceutics 10, 417427.

(11) Liu, C., Yang, Y., Chen, L., Lin, Y.-L., and Li, F. (2014) A Unified Mechanism for Aminopeptidase N-based Tumor Cell Motility and Tumor-homing Therapy. J. Biol. Chem. 289, 34520-34529.

(12) Chen, L., Lin, Y.-L., Peng, G., and Li, F. (2012) Structural basis for multifunctional roles of mammalian aminopeptidase N. Proc. Natl. Acad. Sci. U. S. A. 109, 17966-17971.

(13) Wei, Y., Yin, G., Yin, H., Yan, D., Ma, C., Huang, Z., Liao, X., Yao, Y., and Chen, X. (2013) Inhibiting Effects of a Cyclic Peptide CNGRC on Proliferation and Migration of Tumor Cells In Vitro. Int. J. Pept. Res. Ther. 19, 163-173.

(14) Li, G., Wang, X., Zong, S., Wang, J., Conti, P. S., and Chen, K. (2014) MicroPET Imaging of CD13 Expression Using a $64 \mathrm{Cu}-$ Labeled Dimeric NGR Peptide Based on Sarcophagine Cage. Mol. Pharmaceutics 11, 3938-3946.

(15) Van Hensbergen, Y., Broxterman, H. J., Elderkamp, Y. W., Lankelma, J., Beers, J. C. C., Heijn, M., Boven, E., Hoekman, K., and Pinedo, H. M. (2002) A doxorubicin-CNGRC-peptide conjugate with prodrug properties. Biochem. Pharmacol. 63, 897-908. 
(16) Ndinguri, M. W., Solipuram, R., Gambrell, R. P., Aggarwal, S., and Hammer, R. P. (2009) Peptide Targeting of Platinum Anti-Cancer Drugs. Bioconjugate Chem. 20, 1869-1878.

(17) Zhang, Z., Hatta, H., Tanabe, K., and Nishimoto, S. i. (2005) A New Class of 5-Fluoro-2'-deoxyuridine Prodrugs Conjugated with a Tumor-Homing Cyclic Peptide CNGRC by Ester Linkers: Synthesis, Reactivity, and Tumor-Cell-Selective Cytotoxicity. Pharm. Res. 22, 381-389.

(18) Postma, T. M., and Albericio, F. (2013) N-chlorosuccinimide, an efficient peptide disulfide bond-forming reagent in aqueous solution. RSC Adv. 3, 14277-14280.

(19) Sun, W.-C., Gee, K. R., Klaubert, D. H., and Haugland, R. P. (1997) Synthesis of Fluorinated Fluoresceins. J. Org. Chem. 62, 64696475.

(20) Plesniak, L. A., Salzameda, B., Hinderberger, H., Regan, E., Kahn, J., Mills, S. A., Teriete, P., Yao, Y., Jennings, P., Marassi, F., and Adams, J. A. (2010) Structure and activity of CPNGRC: a modified CD13/APN peptidic homing motif. Chem. Biol. Drug Des. 75, 551562.

(21) Su, L., Cao, J., Jia, Y., Zhang, X., Fang, H., and Xu, W. (2012) Development of Synthetic Aminopeptidase N/CD13 Inhibitors to Overcome Cancer Metastasis and Angiogenesis. ACS Med. Chem. Lett. $3,959-964$

(22) Miki, T., Takegami, Y., Okawa, K., Muraguchi, T., Noda, M., and Takahashi, C. (2007) The Reversion-inducing Cysteine-rich Protein with Kazal Motifs (RECK) Interacts with Membrane Type 1 Matrix Metalloproteinase and CD13/Aminopeptidase N and Modulates Their Endocytic Pathways. J. Biol. Chem. 282, 12341-12352.

(23) Yeager, C. L., Ashmun, R. A., Williams, R. K., Cardellichio, C. B., Shapiro, L. H., Look, A. T., and Holmes, K. V. (1992) Human aminopeptidase $\mathrm{N}$ is a receptor for human coronavirus 229E. Nature $357,420-422$.

(24) Zhang, S., Lin, F., Hossain, M. A., Shabanpoor, F., Tregear, G. W., and Wade, J. D. (2008) Simultaneous Post-cysteine(S-Acm) Group Removal Quenching of Iodine and Isolation of Peptide by One Step Ether Precipitation. Int. J. Pept. Res. Ther. 14, 301-305. 